\title{
Cannabis Legalization: Perceptions of Psychiatrists and Recovering Users
}

\author{
Giovana Alessandra Wink ${ }^{*}, 1$ \\ Orcid.org/0000-0003-4998-0161 \\ Cristina Pilla Della Méa ${ }^{1}$ \\ Orcid.org/0000-0002-8733-1560 \\ Tainá Rossi ${ }^{2}$ \\ Orcid.org/0000-0002-4131-4247
}

${ }^{1}$ Faculdade Meridional (IMED), Passo Fundo, RS, Brasil

${ }^{2}$ Pontifícia Universidade Católica do Rio Grande do Sul, Porto Alegre, RS, Brasil

\begin{abstract}
The legalization of cannabis in Brazil is a topic that is currently being discussed. As well as public health issues, it also involves social, legal and educational aspects. Accordingly, this study aimed to verify the perception of psychiatrists and recovering cannabis users regarding the legalization of cannabis in Brazil. This was an exploratory qualitative study. The study included 20 participants aged 26 to 71 ( $80 \%$ male), 10 composing the group of psychiatrists, and 10 the group of recovering cannabis users. Semi-structured interviews were performed and analyzed using content analysis. The majority of the participants $(85 \%)$ were not in favor of cannabis legalization Brazil. The reports mentioned physical, psychic and social damage, as well as the absence and inefficiency of public policies. However, they were positive regarding cannabidiol treatments for refractory diseases. More studies are needed that contemplate this theme, encompassing other populations, in order to provide better explanations.
\end{abstract}

Keywords: Cannabis, cognitive dysfunction, therapeutic use, legislation, social conditions, drug trafficking, substance withdrawal syndrome.

\section{Legalização da Maconha: Percepção de Psiquiatras e de Usuários em Recuperação}

\section{Resumo}

A legalização da maconha no Brasil é um tema que vem sendo discutido atualmente, pois além de questões sobre saúde pública, envolve também aspectos sociais, jurídicos e educacionais. Portanto, o estudo teve como objetivo verificar a percepção de médicos psiquiatras e usuários de maconha em recuperação sobre a legalização de maconha no Brasil. Trata-se de uma pesquisa qualitativa exploratória. O estudo foi composto por 20 participantes com idades entre 26 e 71 anos ( $80 \%$ do sexo masculino),

* Mailing address: Rua 15 de Novembro, 735, sala 04, Centro, Passo Fundo - RS, Brazil 990100-90. E-mail: giovana_alessandra@hotmail.com and cristina.mea@imed.edu.br 
10 compondo o grupo de médicos psiquiatras, e 10 usuários de maconha em recuperação. Foi aplicada uma entrevista semiestruturada, e utilizada a análise de conteúdo. A maioria dos participantes se posicionaram de maneira desfavorável $(85 \%)$ a legalização da maconha Brasil. Os relatos incluíram prejuízos físicos, psíquicos e sociais, bem como a ausência e ineficácia de políticas públicas. Porém, tiveram postura positiva aos tratamentos com canabidiol para doenças refratárias. Portanto, necessitase de mais pesquisas que contemplem este tema, abarcando outras populações a fim de trazer melhores esclarecimentos.

Palavras-chave: Cannabis, disfunção cognitiva, uso terapêutico, legislação, condições sociais, tráfico de drogas, síndrome de abstinência a substâncias.

\section{Legalización de la Marihuana: Percepción de Psiquiatras y de Usuarios en Recuperación}

\section{Resumen}

La legalización de la marihuana en Brasil es un tema que viene siendo discutido actualmente, pues además de cuestiones sobre salud pública, involucra también aspectos sociales, jurídicos y educativos. Por lo tanto el estudio tuvo como objetivo verificar la percepción de médicos psiquiatras y usuarios de marihuana en recuperación sobre la legalización de marihuana en Brasil. Se trata de una investigación cualitativa exploratoria. El estudio fue compuesto por 20 participantes con edades entre 26 y 71 años (80\% del sexo masculino), 10 componiendo el grupo de médicos psiquiatras, y 10 usuarios de marihuana en recuperación. Se aplicó una entrevista semiestructurada, y se utilizó el análisis de contenido. La mayoría de los participantes se posicionaron de manera desfavorable ( $85 \%$ ) la legalización de la marihuana en Brasil. Los relatos incluyeron pérdidas físicas, psíquicas y sociales, así como la ausencia e ineficacia de políticas públicas. Pero tuvieron postura positiva a los tratamientos con canabidiol para enfermedades refractarias. Por lo tanto, se necesitan más investigaciones que contemplen este tema, abarcando otras poblaciones a fin de traer mejores aclaraciones.

Palabras clave: Cannabis, disfunción cognitiva, uso terapêutico, legislación, condiciones sociales, tráfico de drogas, síndrome de abstinência a substancias.

Drug legalization policies have been debated due to the advance of critical discourses related to the criminalization of certain substances, as well as the distancing of the power of government in the management of drug circulation. From the permissiveness declared by some countries, the first legislative proposals were made in the National Congress regarding the legalization of cannabis in Brazil, promoting scientific studies related to this theme (Lemos \& Rosa, 2015). In the epidemiological ranking of use of this substance, Brazil is in $17^{\text {th }}$ place when considering people who have tried cannabis at least once. The leading countries are Canada, New Zealand, Italy and the United Kingdom (National Institute of Public Policy for Alcohol and Other Drugs [INPAD], 2012).
Accordingly, it is necessary to differentiate between criminalization, decriminalization, regulation/legalization. Criminalization refers to the prohibition of use, cultivation and sale, which may lead to legal penalties for the individual who fails to comply with the law. Decriminalization is to make the recreational use and sale of the substance in specific places official, where the user does not suffer punishment, a fact that does not guarantee a solution for the problems related to drug trafficking. However, regulation means allowing legal standards to be established for consumption, marketing and quality of the product. In this way, the economy of the country is influenced and the black market (trafficking) loses space due to not providing 
the same guarantees, with the State having responsibility. To legalize means to permit the use, in the broad sense, cultivation and commercial distribution. However, it is not enough to simply legalize cannabis, there is a need for well-established rules and standards (Kiepper \& Esher, 2014).

Cannabis (cannabis sativa) is the third most widely consumed drug in the world, following cigarettes and alcohol (Hall \& Weier, 2015). Among the illicit drugs, it ranks first in consumption, with approximately 180 million users worldwide, mostly aged 15-64 (World Health Organization [WHO], 2016). In Brazil, the II National Survey of Alcohol and Drugs (LENAD) estimated that among adolescents, $4.3 \%(597,510)$ had consumed cannabis at least once in their life and among adults, at least $6.8 \%$ (7,831,476; INPAD, 2012).

In Brazil, there is a distinction between licit substances (alcohol and tobacco) and illicit substances. Law No. 11.343, of 2006, established that the individual who is in possession of drugs for their own consumption would no longer receive a custodial sentence. According to art. 28, whoever purchases, possesses, stores, transports or carries drugs for personal consumption without authorization or in disagreement with legal or regulatory determination, shall be subject to the following penalties: warning about the effects of drugs; provision of services to the community; educational measure of attendance of a program or educational course (Sistema Nacional de Políticas Públicas sobre Drogas [SISNAD], 2006).

In Brazil, the Federal Medical Council (2014) through Resolution No. 2.113/2014 authorized the compassionate use of CBD for the treatment of epilepsy in children and adolescents, refractory to conventional treatments. Therefore, the Brazilian Health Regulatory Agency (ANVISA), through Resolution No. 156 of May 5,2017 , allows cannabis as a future component in the registration of medications or regulations to be discussed as a medicinal plant (2017).

Cannabis sativa is a dioecious plant that produces approximately 80 cannabinoids, the main ones being delta-9-tetrahydrocannabinol
(THC) responsible for the sensation of pleasure and being able to cause dependence, and CBD, which has a therapeutic effect and is widely used in medicines (American Psychiatric Association [APA], 2014; Karniol, 2010; Oga, 2014; Zuardi \& Crippa, 2011). Physical and psychological damage can be caused by THC (Rezkalla, Stankowski, \& Kloner, 2016; Zuardi \& Crippa, 2011), including symptoms of bronchitis, acute myocardial infarction, stroke (WHO, 2016), working memory impairment, psychomotor agitation, mood changes, anxiety, mental confusion and, in some cases, psychotic symptoms (Oga, 2014; Secretaria Nacional de Políticas sobre Drogas, 2011; Svrakic et al., 2012). Chronic impairments mainly occur when cannabis is used on a regular basis, daily for months or years (Hall \& Lynskey, 2009).

Cannabidiol is being used for different pathologies, with it having been approved in various countries, even acknowledging the need for further studies related to the effectiveness of this treatment (Matos et al., 2017; Udow, Freitas, Fox, \& Lang, 2018). In addition, countries such as Uruguay and approximately 21 American states, such as Colorado and Washington, have regulated its use, including recreational use (Pamplona, 2014).

Due to the growing public acceptance of the recreational use of cannabis and the ineffectiveness of the control system, a debate has arisen characterized by emotional influence, since people who are in favor of legalization are somewhat unaware of the effects that cannabis use can cause on the health of users, while people against legalization seem to ignore the fact that substances that are currently licit, such as cigarettes and alcohol, also cause harm and have negative effects on the health of their users (Hall \& Lynskey, 2009).

Due to its great complexity, cannabis legalization is related to public health issues and social, legal and educational aspects (Babín, 2013; Larajeira, 2010). Aiming to comprehend what Brazilians think about the decriminalization and legalization of cannabis, Moreira, Carvalho, Ribeiro, and Fernandes (2016) found that $57.8 \%$ of the participants did not have specific 
knowledge about the subject, demonstrating the need to deepen this theme. In addition, there is no agreement between the debates, making it of important social and academic relevance. Therefore, the aim of this study was to investigate the perception of psychiatric physicians and recovering users regarding the legalization of cannabis in Brazil. It was also sought to compare the opinion of the psychiatry professionals with that of the recovering users regarding the legalization of this drug.

\section{Method}

\section{Design}

This was an exploratory, qualitative study.

\section{Participants}

A total of 20 participants, aged between 26 and 71 years, $80 \%$ male, were recruited by convenience in a psychiatric clinic and therapeutic community in the North of the state of Rio Grande do Sul. Of these participants, 10 composed the group of psychiatric physicians, who worked in the clinic, were aged between 37 and 71 years and were $90 \%$ men. The other 10 composed the group of recovering cannabis users, the average number of participants in post-discharge therapy meetings (which aims to provide ex-offenders with a moment to exchange experiences about the tools used to maintain abstinence, with weekly meetings to assist in the recovery process), aged between 26 and 44 years, with $70 \%$ men.

The term recovering users was employed, due to the provisions of Law 8080/90, of the Ministry of Health (1990), which concerns the promotion, protection, and recovery of health. In this way, it is understood that abstinence is a process in which the health of the user is being recovered. The inclusion criterion for the group of psychiatric physicians was to perform psychiatric hospitalizations due to the use of psychoactive substances. The exclusion criterion was not having experience with patients dependent on psychoactive substances. For the group of recovering users, the inclusion criteria were: (1) to be 18 years of age or over; (2) to have been hospitalized at least once due to cannabis use disorder; (3) and to be receiving psychiatric and psychological treatment due to abstinence from cannabis. The exclusion criteria were: (1) to have been abstinent from cannabis use for less than 1 year; (2) to have a history or medical diagnosis of psychiatric comorbidity; (3) and to have made use of other drugs.

\section{Instruments}

A semi-structured interview was used, based on the following questions: (1) What do you understand by the legalization of cannabis? (2) What is your opinion regarding cannabis being legalized in Brazil? (3) What positive or negative consequences could the liberation of cannabis have on society? (4) From your understanding, what can lead to frequent cannabis use in the user?

\section{Ethical Procedures}

The study was approved by the Ethics Committee (CAAE 56468616.2.0000.5319), and followed all the directives that guide studies with human subjects.

\section{Data Collection Procedures}

The choice of the clinic was made by convenience, from the contact network of one of the researchers. To obtain institutional consent, the aims and how the data collection would be performed were presented. Upon agreeing to participate, the person in charge of the clinic signed an institutional consent form. Days and times for the data collection were then agreed. The participants were informed about the study and it was made clear that they were not required to participate, that their identity would be kept completely confidential and that they could withdraw from the study at any time. Upon accepting, they signed the consent form. The participants of the psychiatric physician group were interviewed individually in the clinic, with an approximate duration of 60 minutes. The recovering cannabis users 
were contacted in the post-discharge group meetings at the same clinic, which held their meetings once a week in a reserved room. Data collection was carried out individually, with a duration of approximately 40 minutes, at a time and place that was convenient for each participant.

The data collection was recorded, transcribed in full for later analysis and the material was destroyed upon conclusion of the study. The results were shared at the clinic in a meeting with the psychiatric physicians and a weekly post-discharge meeting with the recovering cannabis users.

\section{Data Analysis Procedures}

The data from the semi-structured interviews was analyzed using content analysis (Freitas, Cunha, \& Moscarola, 1997). This process followed the technical steps proposed by Bardin (2009): (1) Pre-analysis: free-floating reading with brief selection of the material; (2) Exploration of the material: listing possible categories, using phrases and words repeated throughout the statements of the participants; (3) Treatment of results, interpretation and inference: organization of the results, with critical investigation of the content.

\section{Results and Discussion}

The majority of the participants in this study, $90 \%$ of the psychiatric physicians and $80 \%$ of the recovering cannabis users, were against legalizing cannabis in Brazil. These data corroborate the INPAD survey (2012), which interviewed 4,607 Brazilians in all regions of the country, resulting in the finding that $75 \%$ of the Brazilian population was against the legalization of cannabis, while $11 \%$ favored it, $9 \%$ did not know how to respond and 5\% did not respond.

Thus, the results regarding the perception of psychiatric physicians and recovering cannabis users on cannabis legalization in Brazil were divided into four categories: (1) Legalization of cannabis in Brazil; (2) Equivalence and implications of legalization; (3) Psychological, physical and social effects; (4) Medicinal use.

\section{Category 1: Legalization of Cannabis in Brazil}

This category included the participant's perceptions regarding the conditions and interests of this debate in Brazil. The findings regarding the group of psychiatric physicians $(\mathrm{P})$ and recovering cannabis users $(\mathrm{S})$ were:

P1: To liberate a substance that has a harmful risk... in a society where education and culture are very limited, where moral and ethical parameters are very corrupt... where there is a lack of social organization and access to public health ... the real risks are very reckless.

P2: "I think this is not a priority, Brazil has so many basic needs . . considering, mainly at this moment, social and economic issues, I think it would be more of a problem for Brazil".

P5: Legalization opens a huge precedent for a country that cannot even deal with the laws that are already in force ... it will not work ... historically cannabis was banned in the 1930s, precisely because of the damage it caused, we are going to undo all this history and restart the whole problem.

P6: I think the only purpose the government thinks about regarding the legalization of cannabis, is the economic purpose, to gain taxes, because there is no technical indication for it . . . it is the absurdity that society creates motivated by the economic question.

S4: "I do not think it's a drug strong enough to knock you out".

S7: "I think it would be good, it is bad if you do not know how to take it".

S8: "Our health is already precarious ... the National Health System, for example, would not be able to cope with this demand, the liberation of cannabis would lead to more people needing medical help".

S9: The country does not have an adequate health structure to cope with the demand that will come from legalization . . due to the geographic size of the country. Our public policy of prevention is very weak. . . it would not cope with this demand in the 
necessary way . . as well as the Brazilian culture, education and police structure.

The reports of not legalizing cannabis in Brazil were related to the lack or inefficacy of public policies for health, education and security. In addition, the participants reported that the main interest in this dispute are economic and financial, and claimed that there was no technical indication of the health area for the legalization of the recreational use of a harmful drug such as cannabis.

Historically, the repression of the commerce of this drug in Brazil began in the 1930s, due to continued use and increasing harm from cannabis (Rowan, 2015), which is currently an illicit substance. The harm of this criminalization include work-related issues, since a criminal conviction or police contact related to drugs makes it difficult to get a job or to obtain an occupational license (Kilmer, 2017). In addition, considering the number of users who have ever tried cannabis in Brazil, millions of people could be serving sentences due to not agreeing with the current law, which can be highly traumatic for individuals (Carlini, 2006). The potential benefits of legalization include reducing the burden on law enforcement, increasing tax revenues, reducing the stigma associated with cannabis use, and reducing black-market production (George, Hill, \& Vaccarino, 2018; Kiepper \& Esher, 2014).

Because it is an illicit drug, Brazil suffers many complications due to trafficking, accentuated by the inefficiency of border control, the lack of active presence of the State, and the low remuneration and training of public security professionals. In this way legalization would be an alternative to reduce the strength of trafficking and crime (Bessa, 2010). This could be combined with more severe punitive measures against traffickers, with the objective of isolating them, increasing the chances of recovery of the users (Carlini, 2006).

There are already positive experiences in other countries regarding legalization (Lemos \& Rosa, 2015). For example, after cannabis legalization, the state of Colorado in the USA estimates that it will obtain an sales tax for the year 2020 of US\$149.6 million, while in the year 2015 it produced more tax than was collected on the sale alcohol and tobacco. In addition, it increased the industrial sector, generating 18,000 new jobs (Light, Orens, Rowberry, \& Saloga, 2016). Legalization also allows the government to save the taxes currently being spent on prohibition, investing this money into health promotion and public education programs, raising public awareness and awareness of the harmful effects in order to avoid inappropriate use of cannabis (Hajizadeh, 2016). This strategy can help many countries and states in crisis, as the sale of licit drugs usually drives the market a lot, increasing the collection of revenues for governments.

Therefore, regulating cannabis also entails investment in public education regarding drug, as well as prevention strategies that can educate people about the benefits and harm it can have for the entire nation. In a study performed by Mason, Hanson, Fleming, Ringle, and Haggerty (2015), which aimed to verify the perception of parents that were and were not cannabis users and their children regarding the implementation of cannabis legalization in Washington - USA, small changes in behavior were found towards criminalization and legalization, demonstrating particular uncertainties in the understanding of what was lawful or illegal. Therefore, public health campaigns are necessary for the purpose of guiding families, clarifying questions about this law.

On the other hand, this debate goes beyond the immediate question of reducing expenditure and increasing tax collections, since it is a subject with a great impact on public health, which also means exposing people to the harm caused by the drug (Hall \& Weier, 2015). It has been proven that THC intoxication causes cognitive, motor and perceptual alterations, among them difficulties in directing and exercising other activities that demand high levels of concentration (Bordin, Jungerman, Figlie, \& Laranjeira, 2010; Karniol, 2010). In this way, the focus should also be on the prevention and treatment of dependencies (Bessa, 2010). 
In order to do this, the real effects that a cannabis legalization policy in Brazil could cause in individuals cannot be clear, mainly considering the precariousness of public policies that really function in the country (Alves, 2014). In addition, the regulation would have to be adapted to each place and provide minimum conditions of public safety and preservation of users' health (Lemos \& Rosa, 2015).

\section{Category 2: Equivalence and Implica- tions of Legalization}

The findings encountered in this category highlighted some relationships with drug that are currently licit in Brazil. According to the participants:

P1: "Cannabis is the gateway to other drugs ... the users are using cannabis, soon they are mixing it, soon they are using crack".

P2: "The legalization of alcoholic beverage and cigarette smoking has made them much easier to use . . cannabis would automatically have the same implications".

P6: Legal is something that is good for our lives... How can we have health when smoking cigarettes and drinking alcohol, which are toxic substances. . . how can we legalize something that is harmful to health ... There are certain absurdities, for example, alcohol being legal. Alcohol and cigarettes should be banned because they are bad for health.

P7: The cigarette causes harm to society, to health, to people. Cigarette smoking is not very different from cannabis, alcohol may be even worse than cannabis. And this is sold against even the legal principle, sold to under $18 \mathrm{~s} . .$. and nobody cares about it.

S1: "There is already a conflict related to other drugs like alcohol and cigarettes, which are legal".

S2: "If it were sold at gas stations like cigarettes, they would want to buy it to smoke as well".

S3: "Liberating cannabis is opening a door to an end I already know, and it's no good".

There was a comparison of cannabis to the currently licit drugs in Brazil, alcohol and tobacco, which are also highly harmful to health. In addition, the participants reported that cannabis use can encourage individuals to use other drugs. The first US states to legalize the recreational use of cannabis were Washington and Colorado, employing the same restrictions applied to alcohol and tobacco, which can be sold only to people over 21 . However, with this new legislation, there was an increase in consumption after its legalization (Hickenlooper, 2014).

Even though studies of illicit drugs suggest that cannabis is highly consumed in Brazil, following only the licit drugs. In order to verify which drugs were most consumed by university students, a study found that $50.9 \%$ of students used alcohol, $46.2 \%$ tobacco, and $16.4 \%$ cannabis, the latter being the only ones who presented behavioral risks related to the use of substances. In addition, they found that university students who used alcohol and/or other drugs have more involvement in accidents, law-related problems and did not use protection in sexual relations, exposing themselves to health vulnerabilities (Antoniassi \& Gaya, 2015). In another study that aimed to verify substance use in medical students, $78.00 \%$ used alcoholic beverages, $38.64 \%$ tobacco, and $26.14 \%$ cannabis (Tockus \& Gonçalves, 2008). These data indicate a high consumption of licit and illicit drugs by this population.

The main common characteristic of cannabis, alcohol and tobacco is physical and psychological dependence (Antoniassi \& Gaya, 2015; Carvalho \& Pellegrino, 2015). Some problems caused by these three substances are similar, specifically questions of attention, perception, memory (Bachetti, Fukusima, \& Quaglia, 2017; Lopes, Menezes, Farina, Moraes, \& Bastos, 2015; Solowij \& Pesa, 2010) and symptoms of depression and anxiety (Andreta, Limberger, Schneider, \& Mello, 2018).

Licit and illicit drugs can often replace heavier drugs, such as quitting smoking cannabis and starting to smoke cigarettes, a drug accepted by society, however, not necessarily more beneficial to health, which in a way can favor the user. These strategies are part of harm reduction policies, aimed at reducing the health, 
social and economic impairments caused by the use of substances, whether legal or illegal, without necessarily using abstinence (Carvalho \& Pellegrino, 2015). This tool assists in the construction of the autonomy of the user and their families through sources of education, information and counseling, serving as a social support network (Mangueira, Guimarães, Mangueira, Fernandes, \& Lopes, 2015).

\section{Category 3: Psychological, Physical and Social Effects}

This category covered the issues raised by participants regarding the damage cannabis can cause to the physical, psychological, and social health of its users. The participants stated that:

P1: "There are studies that show that a large percentage, almost 1/4 of patients who use cannabis, between 16 and 24 years old can develop psychotic symptoms . . . due to the toxicity of THC'.

P3: Very important cognitive impairment for the user . . . significant alterations in concentration, memory, attention, psychomotor development, learning difficulties ... in addition to exposing the user to risks such as car accidents and low work and academic performance.

P5: We cannot know that people are freefrom risk ... whether or not they are predisposed to psychiatric illness . . . amotivational syndrome, they have less initiative, produce less, their cognitive potential is reduced. . . psychotic conditions worsen with the use of cannabis.

P8: Professional impairments, in the years of study, career ... surely the most common damage is dependence, psychomotor slowness, memory and learning impairment, less initiative. . . linked to the triggering of paranoid and psychotic conditions ... interfering in people's lives.

P10: "More chance of developing mood disorder, anxiety, and severe psychotic disorders such as schizophrenia . . increases the chance of school dropout . . . amotivational syndrome. . . greater probability of suicidal ideation".
S1: At first it gives you a sense of peace, but it is an initial sensation . . I was anxious, with slow reasoning, difficulty paying attention to things, slowness, laziness . . . I did not want to study, I spent hours in a locked room using, that's not life.

S3: "Forgetfulness... we seek cannabis to get out of this reality and spend a few moments doing nothing . . it destroys the family a lot, it destroys society as a whole".

S7: "It happened to me, hospitalized for psychotic outbreaks, I thought that in one of these my brain would go and not come back, you do not know what is reality anymore... I still have injuries that remain, attention deficit".

S10: "It can trigger schizophrenia, panic syndrome ... dropping out of school ... it affects the professional issue, psychic problems, mood disorder".

Despite a false sense of momentary benefit in the statements of the cannabis users in recovery, continuous use can lead to several, often irreversible, losses, directly influencing school and professional issues. This finding corroborates those of Laranjeira (2010) who found that, because it is a substance that alters the central nervous system, cannabis compromises cognitive and motor functions, increases the risk of accidents and causes a decrease in productivity and performance in work and studies.

Cognitive impairments are observed, both in acute intoxication and in the continuous use of cannabis. The use of this drug in the longterm causes impairments in the processes of attention, inhibition and operational memory, among other executive functions. The onset of use in adolescence is a potentially critical factor, increasing the risk of developing greater brain impairment. In addition, there is evidence that, in the long-term, the frequency, amount and duration of the dose used increase (Solowij \& Pesa, 2010), and that the consequences related to this exposure also increase.

Amotivational syndrome associated with cannabis use was reported by the participants. It consists of symptoms such as: laziness, lack of interest and neglecting personal hygiene. This syndrome is often found in users of psychoactive 
substances (Gutiérrez, Hoyos, \& Vega 2016). Cannabis use can also cause paranoid, psychotic and panic symptoms. These symptoms may evolve into panic disorder and schizophrenia in users with a pre-disposition for psychiatric illness (Marques, Araújo, Laranjeira, \& Zaleski, 2010; Svrakic et al., 2012; Zuardi \& Crippa, 2011).

Individuals with psychiatric disorders are more likely to use psychoactive substances, with people with schizophrenia having a $10.1 \%$ greater chance of using cannabis (Diehl, Cordeiro, \& Laranjeira, 2010), however, they are also less likely to develop cognitive symptoms resulting from this use (Hanna et al., 2016). For individuals with affective disorders, such as manic episodes, the index reaches $14.5 \%$, $4.1 \%$ in individuals with a diagnosis of major depressive disorder, $4.3 \%$ with panic disorder, and $2.4 \%$ in individuals with phobias (Diehl et al., 2010). Among the affective disorders, cannabis use may be a significant predictor of impairment of cognitive functions (Waterreus, Badcock, Prinzio, Martin-Iverson, \& Morgan, 2017).

Negative experiences from the use of cannabis can also constitute a harmful and traumatic factor. For example, being imprisoned for 5 days due to drug-related issues will likely trigger more physical and psychological harm than 5 continuous years of cannabis use (Carlini, 2006). In addition, compulsory treatment for substance users has low evidence of efficacy, showing that this benefits the institutions and people involved in this process more than the patients themselves (Carlini, 2006). In addition, people who make sporadic use of cannabis and enjoy this practice do not usually experience damage from the substance (Kilmer, 2017).

\section{Category 4: Medicinal Use}

This category examined the results reported by the participants regarding the therapeutic use of cannabis. It can be observed that the participants indicated that cannabis may help in some pathologies. According to the participants:

P3: "In some cases, there is medical evidence that it may have a therapeutic effect, control some serious epilepsies, which are refractory to the use of medications that already exist, in this case only".

P7: "There is the positive aspect, which is its use in refractory epileptic people and it has had very good results".

P8: What you have in relation to medicinal use are some substances that do not necessarily have THC, there is cannabidiol that is used for severe cases of epilepsy, there are other synthetic derivatives that are used as analgesics. So it's not the cannabis itself, it's not the cannabis that the kids smoke that is sold.

P9: "In medicinal use, there are substances that lend themselves to this, such as cannabidiol, which is being isolated forming an effective treatment for epilepsy".

S5: "I have heard that there is a substance in cannabis that they use for medical purposes, you see, and this medical end, does not have the part of the drug that gets you high".

S1: "The active component of cannabis as a medication has been widely publicized, as well as the use of cannabis as a sedative".

S4: "It has medicinal benefits".

S10: There are some substances of cannabis that are used for medicinal purposes, I believe that it can be liberated if it is proven to be effective in this way, but these substances that can be manipulated and isolated by laboratories, using only those that do good.

It can be observed that the participants reported the efficacy of the use of cannabis as a strategic substance in the treatment of refractory diseases. The first discoveries of medical cannabis use date back to $900 \mathrm{BC}$ in India, where it was used in religious cults and for the treatment of diseases (Barros \& Peres, 2011). Scientific studies related to CBD emerged in the twentieth century, raising the hypothesis of its therapeutic use. Currently, the use of CBD is authorized in several countries, including Brazil, through judicial decisions that support families of patients who are treated in cases of epilepsy, autism and anxiety (Gontijo, Castro, Petito, \& Petito, 2016). The importation of this substance 
is authorized only for medical purposes, since its recreational use is illicit (Bentes, 2015).

In California, since its legalization, three measures have been created: medical cannabis must be distributed in places other than recreational locations; therapeutic use must be accompanied by a medical certificate and parental notification in cases of people under 18 years of age; and the tax revenue collected is used to finance research that considers the damage from legalization in the long-term (Banys \& Cermak, 2016).

Studies have advanced with regard to the use of medical cannabis. Delta-9tetrahydrocannabinol is being tested for the treatment of various diseases, including multiple sclerosis, glaucoma, anorexia associated with Acquired Immunodeficiency Syndrome (AIDS), neuromuscular diseases, migraine, epilepsy, chronic pain, depression and also for the relief of the nausea and vomiting side effects of chemotherapy. Even with the separation of the substances from cannabis, some patients who use therapeutic treatment report some psychological discomfort (Karniol, 2010). Medical cannabis is not soluble in water and, for many patients who do not use it recreationally, smoking it is not a fully accepted practice, with it being preferable to inhale it through vaporization (Pamplona, 2014). The participants of this study were not in favor of the legalization of cannabis in Brazil. Although, they highlighted the physical, psychological and social damage, they also mentioned the benefits of CBD for the treatment of some diseases.

\section{Final Considerations}

Different thoughts and opinions emerged in this debate to those of previous studies around the world. However, the present study found that the majority of the participants, psychiatrists and recovering users were opposed to cannabis legalization in Brazil, highlighting the development of dependence, cognitive, work and psychiatric impairments and, particularly, the development of serious pathologies such as psychotic conditions. On the other hand, there have great advances in studies that advocate the use of cannabis for medical purposes in the treatment of various pathologies. In relation to society, the participants demonstrated concern regarding its legalization, due to the lack of State structure, with discussions on the efficacy and inefficiency of public policies and strategies for prevention and recovery of substance users. There is no consensus in the literature regarding this issue. However, concerning Brazil, with little supervision at the borders and a highly precarious national health system (SUS), it must be considered that this could be one more problem for a country that invests so little in public policies.

Since this is an exploratory study, further studies are needed to deepen the results. As limitations, the investigation of the issue of legalization of cannabis was approached only considering the area of health. As a continuity of the study, the exploration of the perception of other professional areas and categories, as well as the view of active substance users, families, sociologists and the general population is suggested. Therefore, this discussion is necessary both in the academic and social spheres, providing spaces for community participation, with the intention not only of warning about the damage, but also, investigating, with new studies, whether there are benefits that the legalization of cannabis in Brazil might bring. In this scenario, health professionals should act with a focus on psychoeducation, information, care, and drug prevention, assisting users, family members and society as a whole, seeking support and coping strategies in public health.

\section{References}

Alves, K. J. (2014). Drogas e descriminalização: Reflexão sobre o impacto sócio jurídico e a implementação da justiça terapêutica no Brasil. Revista Linhas Jurídias, 6(8), 72-74. Retrieved from http://periodicos.unifev.edu.br/index.php/ LinhasJuridicas/article/view/105/87

American Psychiatric Association. (2014). Manual Diagnóstico e Estatístico de Transtornos Mentais (5th Ed.). Porto Alegre, RS: Artmed. 
Andreta, I., Limberger, J., Schneider, J. A., \& Mello, L. T. N. de. (2018). Sintomas de Depressão, Ansiedade e Estresse em usuários de drogas em tratamento em Comunidades Terapêuticas. Psico USF, 23(2), 361-373. doi: 10.1590/141382712018230214

Antoniassi, G., Jr., \& Gaya, C. de. M. (2015). Implicações do uso de álcool, tabaco e outras drogas na vida do universitário. Revista Brasileira em Promoção da Saúde, 28(1), 6774. doi: 10.5020/18061230.2015.p67

Babín, V. F. de A. (2013). The debate over drug legalization. Adicciones, 25(1), 6-9. Retrieved from http://www.adicciones.es/index.php/ adicciones/article/view/66/65

Bachetti, L. da. S., Fukusima, S. S., \& Quaglia, M. A. C. (2017). O efeito do álcool na percepção visuoespacial e na cognição do espaço. Psicologia, Saúde \& Doenças, 18(2), 451-461. http://dx.doi.org/10.15309/17psd180213

Banys, P., \& Cermak, T. (2016). Marijuana legalization in California: Implementation of the Adult Use of Marijuana Act (AUMA). Journal of Psychoactive Drugs, 48(1), 63-65. doi: 10.1080/02791072.2015.1132350

Bardin, L. (2009). Análise de conteúdo. Lisboa: Edições 70.

Barros, A., \& Peres, M. (2011). Proibição da maconha no Brasil e suas raízes históricas escravocratas. Revista Periferia, 3(2), 1-22. doi: 10.12957/ periferia.2011.3953

Bentes, I. (2015). Ponham as cartas na mesa e discutam essas leis: A luta pela legalização da maconha no Brasil. Argumentum, 7(1), 93-107. doi 10.18315/argumentum.v7i1.9050

Bessa, M. A. (2010). Contribuição à discussão sobre a legalização de drogas. Ciência e Saúde Coletiva, 15(3), 633-636. doi: 10.1590/s141381232010000300004

Bordin, S., Jungerman, F. S., Figlie, N. B., \& Laranjeira, R. (2010). Maconha. In N. B. Figlie, S. Bordin, \& R. Laranjeira (Eds.), Aconselhamento em dependência química (pp. 119-131). São Paulo, SP: Roca.

Brazilian Health Regulatory Agency. (2017). Resolução da diretoria colegiada $R D C n^{\circ} 156$, de 5 de maio de 2017. Retrieved from http://portal. anvisa.gov.br/documents/10181/2718376/ RDC_156_2017_.pdf/8513f1a8-8f85-436aa48c-1ae3e4c6556b
Carlini, E. A. (2006). A história da maconha no Brasil. Jornal Brasileiro de Psiquiatria, 55(4), 314-317. doi: 10.1590/S004720852006000400008

Carvalho, I. S., \& Pellegrino, A. P. (2015). Drogas no Brasil: A mudança já começou. Caderno de Experiências, 16, 1-48. Retrieved from https://igarape.org.br/wp-content/ uploads/2013/05/AE-16_CADERNO-DEEXPERI\%C3\%8ANCIAS_24-03w.pdf

Diehl, A., Cordeiro, D. C., \& Laranjeira, R. (2010). Abuso de cannabis em pacientes com transtornos psiquiátricos: Atualização para uma antiga evidência. Revista Brasileira de Psiquiatria, 32(1), 541-545. doi: 10.1590/ S1516-44462010000500007

Federal Medical Council. (2014). Resolução CFM N $N^{o}$ 2.113/2014. Retrieved from http:// www.portalmedico.org.br/resolucoes/ CFM/2014/2113_2014.pdf

Freitas, H. M. R., Cunha, M. V. M., \& Moscarola, J. (1997). Aplicação de sistemas de software para auxílio na análise de conteúdo. Revista de Administração da USP, 32(3), 97-109. Retrieved from http:/www.ufrgs.br/gianti/ files/artigos/1997/1997_052_RAUSP_Freitas_ Cunha_Moscarola.pdf

George, T. P., Hill, K. P., \& Vaccarino, F. J. (2018). Cannabis legalization and psychiatric disorders: Caveat "Hemp-tor". The Canadian Journal of Psychiatry, 63(7), 447-450. doi: $10.1177 / 0706743718762387$

Gontijo, E. C., Castro, G. L., Petito, A. D. de. C., \& Petito, G. (2016). Canabidiol e suas aplicações terapêuticas. Revista Refacer, 5(1), 1-9. Retrieved from http://ceres.facer.edu.br/revista/ index.php/refacer/article/view/100

Gutiérrez, R., Hoyos, L. V., \& Veja, V. G. (2016). Las condiciones socioculturales del desarrollo del síndrome amotivacional asociado a los consumidores crónicos de marihuana. Caleidosocopio, 19(34), 119-137. Retrieved from http://revistas.psico-ags.net/ index.php/caleidoscopio/article/view/137

Hajizadeh, M. (2016). Legalizing and regulating marijuana in Canada: Review of potential economic, social, and health impacts. International Journal of Health Policy and Management, 5(8), 453-456. doi: 10.15171/ ijhpm.2016.63 
Hall, W., \& Lynskey, M. (2009). The challenges in developing a rational cannabis policy. Current Opinion in Psychiatry, 22, 258-262. doi: 10.1097/YCO.0b013e3283298f36

Hall, W., \& Weier, M. (2015). Assessing the public health impacts of legalizing recreational cannabis use in the USA. Clinical Pharmacology \& Therapeutics, 97(6), 607-615. doi: 10.1002/ cpt.110

Hanna, R. C., Shalvoy, A., Culum, C. M., Keshavan, M., Pearlson, G., Hill, S. K., ...Chose, S. (2016). Cognitive function in individuals with psychosis: Moderation by adolescent cannabis use. Schizophrenia Bulletin, 42(6), 1496-1503. doi: 10.1093/schbul/sbw030

Hickenlooper, J. W. (2014). Experimenting with pot: The state of Colorado's legalization of marijuana. Milbank Quarterly, 92(2), 243-249. doi: 10.1111/1468-0009.12056

Karniol, I. G. (2010). Cannabis sativa e derivados. In S. D. Seibel (Ed.), Dependência de drogas (pp. 234-239). São Paulo, SP: Atheneu.

Kiepper, A., \& Esher, A. (2014). A regulação da maconha no Senado Federal: Uma pauta da Saúde Pública no Brasil. Caderno Saúde Pública, 30(8), 1-3. doi: 10.1590/0102-311XP

Kilmer, B. (2017). Recreational cannabis Minimizing the health risks from legalization. New England Journal of Medicine, 376(8), $705-$ 707. doi: 10.1056/NEJMp1614783

Laranjeira, R. (2010). Legalização das drogas e a saúde pública. Revista Científica Ciência \& Saúde Coletiva, 15(3), 621-631. doi: 10.1590/ s1413-81232010000300002

Lemos, C. J. M. de A., \& Rosa, P. O. (2015). No caminho da rendição: Cannabis, legalização e antiproibicismo. Argumentum, 7(1), 69-92. doi: 10.18315/argumentum.v7i1.9045

Light, M., Orens, A., Rowberry, J., \& Saloga, C. W. (2016). The economic impact of marijuana legalization in Colorado. Marijuana Policy Groupy, 1-22. Retrieved from http://www. mjpolicygroup.com/pubs/mpg\%20impact $\% 20$ of $\% 20$ marijuana $\% 20 \mathrm{on} \% 20$ colorado-final.pdf

Lopes, R. M. F., Menezes, R. C., Farina, M., Moraes, A., \& Bastos, A. S. (2015). Alcoolismo e interferências cognitivas nos processos de atenção e percepção. Journal of Neuropsychology, 9(3), 15-23. doi: $10.7714 / \mathrm{cnps} / 9.3 .203$
Mangueira, S. O., Guimarães, F. J., Mangueira, J. O., Fernandes, A. F. C., \& Lopes, M. V. (2015). Promoção da saúde e políticas públicas do álcool no Brasil: Revisão integrativa da literatura. Psicologia \& Sociedade, 27(1), 157-168. doi: 10.1590/1807-03102015v27n1p157

Marques, A. C. P. R., Araújo, M. R., Laranjeira, R., \& Zaleski, M. (2010). Diretrizes farmacológicas para o tratamento da dependência de maconha. In A. Gigliotti \& A. Guimarães (Eds.), Diretrizes gerais para tratamento da dependência química (pp. 61-63). Rio de Janeiro, RJ: Rubio.

Mason, W. A., Hanson, K., Fleming, C. B., Ringle, J. L., \& Haggerty, K. P. (2015). Washington State Recreational Marijuana Legalization: Parent and adolescent perception, knowledge, and discussions in a sample of low-income families. Substance Use \& Misuse, 50(5), 541-545. doi: 10.3109/10826084. 2014.952447

Matos, R. L. A., Spinola, L.A., Barboza, L. L., Garcia, D. R., França, T. C. C., \& Afonso, R. S. (2017). O uso do canabidiol no tratamento da epilepsia. Revista Virtual de Química, 9(2), 786-814. Retrieved from http://rvq.sbq.org.br/ imagebank/pdf/MatosNoPrelo.pdf

Ministry of Health. (1990). Lei no 8.080, de 19 de setembro de 1990. Brasília, DF: Author. Diário Oficial da União. Retrieved from http://www. planalto.gov.br/ccivil_03/Leis/L8080.htm

Moreira, M. R., Carvalho, A. I. de, Ribeiro, J. M., \& Fernandes, F. M. B. (2016). Agendas democráticas para o século XXI: Percepções dos(as) brasileiros(as) sobre descriminalização e legalização da maconha [Special issue]. Saúde em Debate, 40, 163-175. doi: 10.1590/0103$11042016 \mathrm{~s} 14$

National Institute of Public Policy for Alcohol and Other Drugs. (2012). II Levantamento Nacional de Álcool e Drogas: LENAD. São Paulo, SP: Universidade Federal de São Paulo. Retrieved from http://inpad.org.br/wp-content/ uploads/2014/03/Lenad-II-Relat\%C3\%B3rio. pdf

Oga, S. (2014). Fundamentos de toxicologia (4th Ed.). São Paulo, SP: Atheneu.

Pamplona, F. A. (2014). Quais são e pra que servem os medicamentos à base de Cannabis? Revista da Biologia, 13(1), 28-35. doi: 10.7594/ revbio.13.01.05 
Rezkalla, S., Stankowski, R., \& Kloner, R. A. (2016). Cardiovascular effects of marijuana. Journal of Cardiovascular Pharmacology and Therapeutics, 21(5), 452-455. doi: $10.1177 / 1074248415627874$

Rowan, R. (2015). O grande livro da cannabis: Guia completo de seu uso industrial, medicinal e ambiental. Rio de Janeiro, RJ: Jorge Zahar.

Secretaria Nacional de Políticas sobre Drogas. (2011). Drogas: Cartilha sobre maconha, cocaina e inalantes. Brasília, DF: Author.

Sistema Nacional de Políticas Públicas sobre Drogas. (2006). Lei $n^{\circ} 11.343$, de 23 de agosto de 2006. Brasília, DF: Câmara dos Deputados, Edições Câmara. Retrieved from http://www.camara. gov.br/sileg/integras/790351.pdf

Solowij, N., \& Pesa, N. (2010). Anormalidades cognitivas no uso da cannabis. Revista Brasileira de Psiquiatria, 32(1), 531-540. doi: 10.1590/ S1516-44462010000500006

Svrakic, D. M., Lustman, P. J., Mallya, A., Lynn, T. A., Finney, R., \& Svrakic, N. M. (2012). Legalization, decriminalization \& medicinal use of cannabis: A scientific and public health perspective. Missouri Medicine, 109 (2), 90-98. Retrieved from http://www.naltrexzoneserbia. com/files/MJ_article.pdf

Tockus, D., \& Gonçalves, P. S. (2008). Detecção do uso de drogas de abuso por estudantes de medicina de uma universidade privada. Jornal Brasileiro de Psiquiatria, 57(3), 184-187. doi: 10.1590/S0047-20852008000300005
Udow, S. J., Freitas, M. E., Fox, S. H., \& Lang, A. E. (2018). Exacerbation of psychosis triggered by a synthetic cannabinoid in a 70-year-old woman with Parkinson disease. Mental Health, 190(2), E50-E52. doi: 10.1503/cmaj.170361

Waterreus, A., Badcock, J. C., Prinzio, P. D., MartinIverson, M., \& Morgan, V. A. (2017). The impact of current cannabis use on general cognitive function in people with psychotic illness. Schizophrenia Bulletin, 43(Suppl. 1), 164-171. doi: 10.1093/schbul/sbx021.215

World Health Organization. (2016). The health and social effects of non-medical cannabis use. Genebra, Switzerland: Author. Retrieved from http://www.who.int/substance_abuse/ publications $/$ msbcannabis.pdf?ua $=1$

Zuardi, A. W., \& Crippa, J. A. S. (2011). Maconha. In A. Dielh, D. C. Cordeiro, \& R. Laranjeira (Eds.), Dependência química: Prevenção, tratamento e políticas públicas (pp. 162-165). Porto Alegre, RS: Artmed.

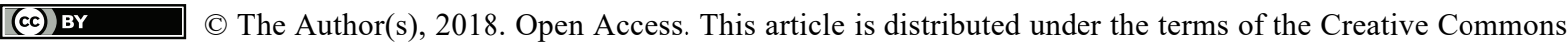
Attribution 4.0 International License (http://creativecommons.org/licenses/by/4.0/), which permits unrestricted use, distribution, and reproduction in any medium, provided you give appropriate credit to the original author(s) and the source, provide a link to the Creative Commons license, and indicate if changes were made. 